\title{
Analysis of physico-chemical properties of textile effluents collected from Sanganer, Jaipur
}

\author{
Ravi Kant Rahi ${ }^{1}$, R. N. Prasad ${ }^{2}$ and Varsha Gupta ${ }^{3}$ \\ ${ }^{1}$ Research Scholar, School of Sciences, JECRC University, Ramchandpura, Sitapura \\ Industrial Area Extn, Vidhani Village, Jaipur, 303905, India \\ ${ }^{2}$ Dean School of Sciences, JECRC University, Ramchandpura, Sitapura Industrial Area Extn, \\ Vidhani Village, Jaipur, 303905, India \\ ${ }^{3}$ Associate professor and Head, Department of Microbiology, JECRC University, \\ Ramchandpura, Sitapura Industrial Area Extn, Vidhani Village, Jaipur, 303905, India
}

\begin{abstract}
The printing and dyeing industries in the area of Sanganer (Jaipur) have been imposing harmful effects on the environment. This study is aimed to compare the physico-chemical properties of textile effluents collected from different sites of Sanganer (Jaipur) with the discharge limits prescribed by World Health Organization. Various parameters like $\mathrm{pH}$, color, temperature, electrical conductivity (EC), biological oxygen demand (BOD), chemical oxygen demand (COD), total hardness, chloride and Total dissolved solids have been determined by prescribed methods. The temperature range was found from $40^{\circ} \mathrm{C}$ to $43^{\circ} \mathrm{C}, \mathrm{pH}$ from 6.7 to 9.3 and electrical conductivity from 3.42 to $4.67 \mu \mathrm{S} / \mathrm{m}$. Total suspended solids (TSS) total dissolved solids (TDS) were found in the range of 4509 to 6370 $\mathrm{mg} / \mathrm{l}$ and 2300 to $3200 \mathrm{mg} / \mathrm{l}$ respectively. Level of chloride content found from 425.7 to $528.2 \mathrm{mg} / \mathrm{l}$ and hardness from 535 to $760 \mathrm{mg} / \mathrm{l}$. Thus all the parameters are in the high range as compared to the limits prescribed by WHO guideline for textile industrial effluent. Hence, there is a need for the treatment of textile effluents before discharging them into the environment.

Keywords: Textile effluents, Physico-chemical parameters, Textile Dyes, RPCB, Sanganer (Jaipur)
\end{abstract}

\section{Introduction:}

In this age and time of rapid industrial, technological and urban development, the world is facing a huge problem of disposing of generated wastes. This waste serves as a pollutant and leads to environmental pollution. Water pollution is a considerate example of such pollution. Polluted water is a mixture of sewage water, industrial effluent and household discharge (Ashraf et al, 2010; European Public Health Alliance, 2009). As WHO report around 1 billion people in the world used polluted water for drinking and around 2.4 billion people lack basic sanitation (WHO, 2004; European Public Health Alliance, 2009).

Industrialization plays a very significant role in a nation's GDP. But rapid industrialization has its own adverse effect. Industries which require water for production purposes use tons of water and discharged it as an effluent in nearby water bodies. Effluent discharged from leather, textile, paper, food and Pharma industries is a mixture of harmful chemical compounds which introduce pollutant to the environment. But textile industries are known to be the most polluted industries as they used verities of chemical and large quantities of water (Qin et al., 2007).

Textile industries are found all over the world and their numbers are increasing day by day. Different types of dyes and dyestuff, including both organic and synthetic, are extensively used in various textile industries. During the processing of textiles, due to the inefficiency of dyeing, a large amount of dyes are being wasted along with wastewater that gets accumulated in the environment (McMullan et al., 2001). This has led to severe pollution in the environment, especially in the aquatic. Effluent discharged from textile industries is one of the 
most serious issues in front of the world (Sriram and Reetha, 2015). Treatment of textile effluent is necessary to get rid of the environmental problem before discharging it into the nearby aquatic system.

Textile Industrial effluents are a mixture of aniline, caustic soda, acids, bleaching powder heavy metals which required at the time of processing and finishing of textiles. After the processing, these chemicals reach to the aquatic system as an effluent discharged from industries. Some of the trace element and heavy metals are required for better growth of microorganism but in very less quantity (Akpoveta et al, 2011). Higher quality of such chemicals leads to bioaccumulation in aquatic animals.

India's largest state Rajasthan represents an authentic art of Sanganer (tie and die printing) which is quite popular in the area. Textile industries present in Sanganer represents an important economic sector of Rajasthan state. The Sanganer town situated $\left(26^{\circ} 49^{\prime}-26^{\circ} 51^{\prime} \mathrm{N}\right.$ latitude and $75^{\circ} 46^{\prime}-75^{\circ} 51^{\prime} E$ longitude) about $20 \mathrm{~km}$ south of the Jaipur (Rajasthan, India) (Jaishree and Khan, 2014).

Textile industries used a various types of azo dyes which are less biodegradable in nature and persist in environment longer period due to more half-life (Goyal and Chauhan, 2014) At the time of processing and finishing, workers of these industries are directly exposed to these dyes and chemicals without any precaution measures (Newhouse, 1978). These industries used gallons of water for processing and they discharged it as an effluent to Dryavati River also known as amani saha nala without any treatment (Joshi and Kumar, 2011).

Industrial waste treatments are harsh and chemical oriented which have harmful effects on the environment. Treatment of textile effluent is necessary to get rid of the environmental problem before discharging it into the nearby aquatic system. Therefore, the search for natural ways to tackle waste management is the need of the hour.

\section{Methods and Methodology}

\subsection{Screening of sampling sites}

For the present study, Sanganer was selected as a study area a very famous town in north India for its beautiful tie and dye technique. Sanganer present nearby world famous city of India "Pink City" Jaipur. Every year thousands of visitors visit Jaipur. Tradition and culture of pink city attracted almost every visitor. Dravyavati river which turns now a drainage system flow throughout the city now known as amani saha nala. sanganer is facing a problem nowadays because of a large number of textile industries present in Sanganer. These industries discharge their effluent into amnai saha nala which affected nearby aquatic life and as well as human.

\subsection{Collection of Samples}

The effluent as a parent source of the sample was collected from Sanganer textile industrial region. For error-free sample collection sample was collected according to sample collection method (APHA, 2005). The sample was collected in sterilized air thigh bottles from the end of the discharged point of textile industries for the present study. After sampling, samples were brought to the laboratory as early as possible and were tested for various physico-chemical parameters. Samples were stored aseptically at $4^{\circ} \mathrm{C}$ after collection. For the present study samples were collected from seven different sites which illustrated in table $\mathbf{1}$.

\subsection{Analysis of Physico-chemical parameters}

Physico-chemical parameters of the textile effluents collected from Sanganer were carried out. parameters such as temperature, color, $\mathrm{pH}$, Conductivity (EC), Chloride, acidity, alkalinity, hardness, chemical oxygen demand (COD), biological oxygen demand (BOD), total dissolved solids (TDS) and total suspended solids (TSS) as prescribed by APHA (2005).

\subsection{Statistical analysis}

All the parameters were performed in triplicates to reduce the degree of error. For Statistical analysis of data software, Microsoft Excel (version 2010) was used. Study of correlation and test of significance has been performed. Correlation coefficient "r" was calculated through below formula:

$r=\frac{\sum x y}{\sqrt{\sum x^{2} \times \sum y^{2}}}$

A significant level of obtained correlation coefficient has been tested through " $t$ " test. 
Table 1: Location details of 7 different sites of sample collection in Sanganer

\begin{tabular}{|c|c|c|c|}
\hline $\begin{array}{l}\text { S. } \\
\text { No. }\end{array}$ & Sites & Location & $\begin{array}{l}\text { Location on } \\
\text { Map }\end{array}$ \\
\hline 1 & Site 1 & $\begin{array}{ll}\text { Near } & \text { Sanganer } \\
\text { bridge } & \text { (Sanganer } \\
\text { Road) } & \\
\end{array}$ & $\begin{array}{l}26^{\circ} 49^{\prime} 08.4^{\prime \prime} \mathrm{N} \\
75^{\circ} 47^{\prime} 25.0^{\prime \prime} \mathrm{E}\end{array}$ \\
\hline 2 & Site 2 & $\begin{array}{l}\text { Near Printing } \\
\text { Unit beside High } \\
\text { Sec. road } \\
\text { Sanganer }\end{array}$ & $\begin{array}{l}26^{\circ} 49^{\prime} 01.1^{\prime \prime} \mathrm{N} \\
75^{\circ} 47^{\prime} 24.5^{\prime \prime} \mathrm{E}\end{array}$ \\
\hline 3 & Site 3 & $\begin{array}{l}\text { Near Printing } \\
\text { Unit beside High } \\
\text { Sec. road } \\
\text { Sanganer }\end{array}$ & $\begin{array}{l}26^{\circ} 48^{\prime} 58.6^{\prime \prime} \mathrm{N} \\
75^{\circ} 47^{\prime} 24.7^{\prime \prime} \mathrm{E}\end{array}$ \\
\hline 4 & Site 4 & $\begin{array}{l}\text { Near Printing } \\
\text { Unit beside High } \\
\text { Sec. road } \\
\text { Sanganer }\end{array}$ & $\begin{array}{l}26^{\circ} 48^{\prime} 40.4^{\prime \prime} \mathrm{N} \\
75^{\circ} 47^{\prime} 27.6^{\prime \prime} \mathrm{E}\end{array}$ \\
\hline 5 & Site 5 & $\begin{array}{ll}\text { Near } & \text { Sanganer } \\
\text { Thana } & \end{array}$ & $\begin{array}{l}26^{\circ} 48^{\prime} 38.3 " \mathrm{~N} \\
75^{\circ} 47^{\prime} 28.8^{\prime \prime} \mathrm{E}\end{array}$ \\
\hline 6 & Site 6 & $\begin{array}{l}\text { Near Bambolla } \\
\text { Road }\end{array}$ & $\begin{array}{l}26^{\circ} 48^{\prime} 16.9^{\prime \prime N} \\
75^{\circ} 47^{\prime} 35.5^{\prime \prime} \mathrm{E}\end{array}$ \\
\hline 7 & Site 7 & $\begin{array}{l}\text { Near Ankit } \\
\text { public School }\end{array}$ & $\begin{array}{l}26^{\circ} 48^{\prime} 06.0^{\prime \prime} \mathrm{N} \\
75^{\circ} 47^{\prime} 31.9^{\prime \prime} \mathrm{E} \\
\end{array}$ \\
\hline
\end{tabular}

\section{Result and Discussion}

Table 2 illustrated the physic-chemical parameters observed in the textile effluent.

\subsection{Temperature and Color:}

The effluent samples collected from different sites of Sanganer were differentially colored. The temperatures of the effluent samples were found in the range of $40.2^{\circ} \mathrm{C}$ to $42^{\circ} \mathrm{C}$. temperature is an important factor as it fluctuates on daily basis. It affects the biotic life present in water as some microorganism requires a specific temperature for growth (Saxena, 1990).

$3.2 \mathrm{pH}$ :

Strength of hydrogen ion concentration in a solution is known as $\mathrm{pH}$. The $\mathrm{pH}$ of the effluent samples was in the range of $6.7-9.3$, which is slightly more than the prescribed limit of wastewater by WHO (6.0 - 9.0) (2006). $\mathrm{pH}$ plays a significant role in the growth of microorganism. Quality of water indirectly depends upon the $\mathrm{pH}$ as it affects the solubility of water (Fakayode, 2005).

\subsection{Electrical Conductivity:}

Electrical conductivity directly related to the number of ions present in a solution. The Electrical conductivity of the effluent samples was in the range $3.42-4.67 \mathrm{~s} / \mathrm{cm}$, which was

Table 2: Physiochemical parameters of effluent samples collected from Sanganer

\begin{tabular}{|c|c|c|c|c|c|c|c|c|c|}
\hline Sample & \multirow{2}{*}{ Site 1} & \multirow{2}{*}{ Site 2} & \multirow{2}{*}{ Site 3} & \multirow{2}{*}{ Site 4} & \multirow{2}{*}{ Site 5} & \multirow{2}{*}{ Site 6} & \multirow{2}{*}{ Site 7} & \multirow{2}{*}{ Mean } & \multirow{2}{*}{$\begin{array}{l}\text { Standard } \\
\text { Deviation }\end{array}$} \\
\hline Parameters & & & & & & & & & \\
\hline $\begin{array}{l}\text { Colour } \\
\text { Appearance }\end{array}$ & Brownish & Yellowish & $\begin{array}{l}\text { White } \\
\text { milky }\end{array}$ & $\begin{array}{l}\text { Pale } \\
\text { yellow }\end{array}$ & $\begin{array}{l}\text { Dark } \\
\text { yellow }\end{array}$ & Yellowish & $\begin{array}{l}\text { Dark } \\
\text { black }\end{array}$ & - & - \\
\hline Temp. $\left({ }^{0} \mathrm{C}\right)$ & 40.2 & 42 & 42 & 43 & 40 & 41 & 41 & 41.3142 & 1.0761 \\
\hline pH & 8.44 & 6.9 & 9.3 & 9.1 & 7.8 & 6.8 & 6.7 & 7.8628 & 1.106 \\
\hline EC (ms) & 3.87 & 3.44 & 3.52 & 3.6 & 4.67 & 3.42 & 4.32 & 3.8342 & 0.485 \\
\hline BOD (mg/l) & 455 & 464 & 425 & 457 & 474 & 455 & 431 & 451.571 & 17.510 \\
\hline COD (mg/l) & 1532 & 1408 & 779 & 755 & 2490 & 1943 & 2131 & 1576.85 & 660.494 \\
\hline TDS (mg/l) & 2839 & 2759 & 2322 & 2300 & 2937 & 3100 & 3200 & 2779.57 & 352.971 \\
\hline TSS (mg/l) & 4809 & 4856 & 4548 & 4509 & 5445 & 6260 & 6370 & 5256.71 & 785.685 \\
\hline $\begin{array}{l}\text { Chloride } \\
(\mathrm{mg} / \mathrm{l})\end{array}$ & 437.6 & 461.4 & 425.7 & 448.3 & 463.5 & 467.6 & 528.2 & 461.75 & 32.956 \\
\hline
\end{tabular}

higher than the prescribed limit of WHO. High EC found Due to the higher concentration of dissolved salt present in effluent (Tekade et al, 2011). A higher value of Electrical conductivity affected plant growth (Ademoroti, 2011).

\subsection{Biological oxygen demand:}

The biological oxygen demand shows the value of organic matter present in water. A higher value of organic matter leads to higher BOD value (Savin and Butnaru, 2008). BOD of all samples was found in the range $425-474 \mathrm{mg} / \mathrm{l}$ which is much higher than the limit prescribed by WHO. It indicates the oxygen level in water is very less in the effluentaffected area. Less oxygen level in water affects the aquatic life.

\subsection{Chemical oxygen demand:}

For Chemical oxygen demand WHO set a limit of $150 \mathrm{mg} / \mathrm{l}$ but in present effluent samples COD 
found 755-2490 mg/l much higher from prescribed limit. A higher value of COD showed the presence of a toxic substance which is biological resistant (Lakhande et al, 2011).

\subsection{Total Dissolved Solids:}

Total dissolved solids (2300-3200 mg/l) were also found with higher range than the prescribed limit by WHO. Higher concentration of dissolved solids in water is harmful to plant growth as it affected the aeration, permeability and soil structure (Suriyanarayanan et al, 2012).

\subsection{Chloride and Hardness:}

Chloride content of all the samples collected from Sanganer were in the range of (425.7 - $528.2 \mathrm{mg} / \mathrm{l})$ which was quite high in comparison to the standard value of drinking water $(250 \mathrm{mg} / \mathrm{L})$. Level of chloride found more due to the presence of chlorine content like hypochloric acid and hydrochloride acid was used extensively in textile industries at the time of processing. The higher amount of chloride effects on biotic life. Total Hardness values observed for textile effluents samples were in the range of $(560-760 \mathrm{mg} / \mathrm{l})$.

Table 3: Effluent parameter quality correlation matrix

\begin{tabular}{|l|l|l|l|l|l|l|l|l|}
\hline Parameters & pH & EC & BOD & COD & TDS & TSS & Chloride & Hardness \\
\hline pH & 1 & -0.1607 & -0.1943 & -0.7111 & -0.8691 & -0.8032 & -0.7573 & -0.7382 \\
\hline EC & & 1 & 0.1887 & 0.7213 & 0.4562 & 0.3590 & 0.4691 & 0.3901 \\
\hline BOD & & & 1 & 0.3577 & 0.1478 & -0.0845 & -0.1472 & -0.2658 \\
\hline COD & & & & 1 & 0.8965 & 0.7784 & 0.6241 & 0.5875 \\
\hline TDS & & & & & 1 & 0.8916 & 0.7393 & 0.7029 \\
\hline TSS & & & & & & 1 & 0.8157 & 0.8653 \\
\hline Chloride & & & & & & & 1 & 0.9699 \\
\hline Hardness & & & & & & & 1 \\
\hline
\end{tabular}

3.8 Statistical analysis

" $t$ " test has been used to calculate the degree of significance in the observed correlation coefficient. Between two parameters total 28 correlations were observed illustrated in table 3. Total 10 cases showed a negative correlation. $\mathrm{pH}$ showed a negative correlation with each parameter.

\section{Conclusion}

Textile industries a major economic zone of India generate opportunity to lots of people. Many lives depend upon the textile industries. But textile industries became problematic as they consider the most polluted industries. A solution is required for effluent which is discharged by these industries as it is a major pollutant to water pollution. Textile effluent is hard to treat as it is a mixture of chemicals. It is a high time to control textile pollutant as they make the environment bad to worse. This study shows all the physiochemical parameters were not in the range. They found very high as a comparison of prescribed limit of WHO. This is a hard time we have to take the action to get rid or get reduce this textile pollutant. High level of these parameters affected aquatic life as well as human life. Before discharging it into the nearby aquatic system or a stream, effluent needs to be treated carefully.

\section{References}

[1] Ademoroti, C M A, Standard Method for water and effluents analysis, Foludex press Ltd, Ibadan 22-23, 4454, 111-112,(2011).

[2] Akpoveta, O. V., Egharevba, F. and Medjor, O. W., A pilot study on the biodegradation of hydrocarbon and its kinetics on kerosene simulated soil. International Journal of Environmental Sciences, Vol. 2(1), Pg: 54-67 (2011).

[3] APHA. "Standard Methods for Examination of Water and Wastewater", American Public Health Association WWA, Washington, D.C. (2005).

[4] Ashraf, M. A., Maah, M. J., Yusoff, I., and Mehmood, K. Effects of Polluted Water Irrigation on Environment and Health of People in Jamber, District Kasur, Pakistan. International Journal of Basic \& Applied Sciences, 10(3), pp. 37-57 (2010).

[5] European Public Health Alliance, Air, Water Pollution and Health Effects. Retrieved from http://www.epha.org/r/54 (2009). 
[6] Fakayode, S.O., Impact Assessment of Industrial Effluent on Water Quality of the Receiving ALaro River in Ibada (2005).

[7] Jaishree and Khan, T.I., Monitoring of Heavy Metal in Textile Waste Water of Sanganer, Jaipur (Rajasthan). International Journal of Scientific and Research Publications, Volume 4, Issue 3, March (2014).

[8] Joshi N. and Kumar A., Physicochemical Analysis of Soil and Industrial Effluents of Sanganer Region of Jaipur Rajasthan. Research Journal of Agricultural Sciences. 2 (2): 354-356, (2011).

[9] Lakhande R.S., Singare P.U. and Pimple D.S., Study on physico chemical parameters of waste water effluents from Taloja industrial area of Mumbai, India, Int. J. Eco., 1(1), 19, (2011).

[10] McMullan, G., Meehan, C., Conneely, A., Kirby, N., Robinson, T., Nigam P., Banat, I., Marchant, R., Smyth, W., Microbial decolourisation and degradation of textile dyes. Volume 56, Issue 12, pp 81-87 July (2001).

[11] Newhouse ML: Mortality study of bleachers and dyers. Ann Occup Hyg 21: 293-296, (1978)

[12] Priya Goyal and Chauhan, S.S., Impact Of Textile Waste Water On Agricultural Fields: A Case Study Of Sanganer Town, Jaipur. International Journal of Geology, Earth \& Environmental Sciences Vol. 4 (1): 37-44, (2014).

[13] Qin, J-J., Oo, M.H., Tao, G. and Kekre, K.A., Feasibility study on petrochemical wastewater treatment and reuse using submerged MBR. Journals of Membrane Science, 293, 161-166, (2007).

[14] Savin I. I. and Butnaru R., Waste water characteristics in textile finishing mills, J. Environ. Engin., 7(6), 859-864, (2008).

[15] Saxena, R., Limnological and water quality status of the Lower Lake of Bhopal with special reference to certain phytoplankton, microinvertebrates and microbiological component. Barkatullah University, Bhopal. (1990).

[16] Sriram, N., and Reetha, D., Isolation and characterization of dye degrading bacteria from textile dye effluents. Central European Journal of Experimental Biology, 4 (2):5-10 (2015).

[17] Suriyanarayanan S., Jessen G., Divya L. and Balasubramanian S., Effect of waste paper industry effluents on growth of tree seedlings, J. Environ. Res. Develop., 7(2A), 1117-1126, (2012).

[18] Tekade P. V., Bawankar S. V. and Mohabansi N. P., Physico-chemical and microbiological ananlysis of textile industry effluent of wardha region, Water R \&D , 1(1), 40-44, (2011).

[19] WHO Guidelines for technologies for water supply systems in small communities (World Health Organization, CEHA) (2006).

[20] WHO's Guideline for Drinking Water Quality, set up in Geneva, are the International reference point for Standard Setting and Drinking Water Safety (1993). 